\title{
First-line therapy with LPV/r vs NVP and 2 NRTls in a developing country: W144 of a randomized trial
}

\author{
Nathan Clumeck, Claude Mwamba, Kabamba Kabeya, Vincent Calvez, Serge Matanda, Dolorès Vaira, \\ Gilles Peytavin, Coca Necsoi, Marc Delforge, David Kadiebwe, Chantal Milolo, Joe Ilunga, Liévin Kapend \\ From International Symposium HIV and Emerging Infectious Diseases 2014 \\ Marseille, France. 21-23 May 2014
}

\begin{abstract}
Aim
In resource-limited countries, NNRTI-based regimen may result in emergence of more HIV drug resistance because of a low genetic barrier. We compare the efficacy and tolerance of LPV/r and NVP-based regimens and 2 WHO nucleoside backbones in naive HIV infected patients (p.).
\end{abstract}

\section{Materials and methods}

Naive p. from 5 clinics in Lubumbashi (Congo-DRC) were randomized to receive $\mathrm{LPV} / \mathrm{r}$ versus NVP combined with TDF/FTC or ZDV/3TC. VL and CD4 were performed at baseline (BL) and every 24 weeks (W). The primary endpoint was the $\%$ of $p$. with therapeutic failure defined as clinical and virologic failures $(\mathrm{VL}>1000 \mathrm{c} / \mathrm{ml})($ missing data=failure), assessed at W48 and 96. We present here the results of $144 \mathrm{~W}$ of follow-up.

\section{Results}

425 Black African p. (72\% female; median (md) age 38 years, md CD4 165/ $\mu \mathrm{L}$; md VL $5.2 \log \mathrm{c} / \mathrm{ml}$ ) were randomized (216 in LPV/r, 209 in NVP). BL characteristics were comparable. In the ITT analysis, previous results showed no difference between LPV/r and NVP treatment arms at W96 except a higher proportion of virologic failure (VF) in p. on NVP-based regimens. W144 ITT analysis showed a significant difference on endpoints between $\mathrm{LPV} / \mathrm{r}(94 / 216)$ and NVP $(111 / 209)(\mathrm{p}=0.0479)$ and persistence of a significant difference in VF rate $(20 / 216 \mathrm{vs}$ $37 / 209$ for $\mathrm{LPV} / \mathrm{r}$ and NVP, respectively $)(\mathrm{p}=0.015)$. BL genotypes showed NNRTI mutations (mt) in 3/31 NVPfailing $\mathrm{p}$. and no PI $\mathrm{mt}$ in LPV/r-failing patients. At time of failure, NNRTI mt were seen in 23/26 NVP-failing p. and $0 / 13$ primary PI $\mathrm{mt}$ in $\mathrm{LPV} / \mathrm{r}$ failing patients. NRTI

Saint Pierre University Hospital, Brussels, Belgium mt were seen in 19/26 p. in NVP arm (including K65R in 7p. and M184V in 18p.) vs 3/13p. in LPV/r arm (M184V in $3 \mathrm{p}$.).

Md CD4 change from BL was significant higher in LPV/ $r$ arm (251 cells/ $\mu \mathrm{L}$ [interquartile range (IQR) 153;384]) compared with NVP arm $(174$ cells $/ \mu \mathrm{L}$ [IQR 102-330])(p= 0.0093). Percentage of $p$. with adherence $>95 \%$ was similar (73.6 vs 74.4 for $\mathrm{LPV} / \mathrm{r}$ vs NVP).

\section{Conclusions}

In a resource-limited setting after 144 weeks of follow-up NNRTI-NRTI first-line regimen is associated with more virologic failure, more drug resistance mutations and a lower immunologic response than a PI-based regimen.

Published: 23 May 2014

doi:10.1186/1471-2334-14-S2-O2

Cite this article as: Clumeck et al:: First-line therapy with LPV/r vs NVP and 2 NRTIs in a developing country: W144 of a randomized trial. BMC Infectious Diseases 2014 14(Suppl 2):O2.

Submit your next manuscript to BioMed Central and take full advantage of:

- Convenient online submission

- Thorough peer review

- No space constraints or color figure charges

- Immediate publication on acceptance

- Inclusion in PubMed, CAS, Scopus and Google Scholar

- Research which is freely available for redistribution 